\title{
Pathoecology and paleodiet in Postclassic/Historic Maya from Northern Coastal Belize
}

\section{Christine White/ ${ }^{+}$, Jay Maxwell*, Alexis Dolphin, Jocelyn Williams**, Fred Longstaffe***}

\author{
Department of Anthropology *Department of Anatomy and Cell Biology ***Department of Earth Sciences, \\ The University of Western Ontario, London ON N6A 5C2, Canada **Department of Anthropology, Trent University, \\ Peterborough, ON K9J 7B8, Canada
}

This paper examines the synergism among diet, disease, and ecology at two related coastal Maya sites in Belize (Marco Gonzalez and San Pedro) for the Postclassic and Historic periods (1350-1650 AD), which immediately follow the Classic period collapse. Stable carbon- and nitrogen-isotope ratios in collagen and stable carbonisotope ratios in structural carbonate were analysed for bones from 65 humans and a wide variety of faunal species. There are no apparent differences in whole diets or degree of carnivory between individuals with lesions indicative of anemia and those without, but those with lesions appear to have consumed significantly more $\mathrm{C}_{4}$ foods and protein from lower trophic levels. Non-specific infection (periostitis) and vitamin C deficiency (scurvy) are also present in high frequencies and appear to co-occur with lesions indicative of anemia, particularly in childhood. Individuals with scurvy also appear to have consumed significantly more $\mathrm{C}_{4}$ foods than normal individuals. Spondyloarthropathy is common in adults. These findings are discussed in light of: (1) the debate on how anemia versus scurvy are manifest and diagnosed, (2) Spanish ethnohistoric descriptions of the poor state of Maya health at the time of contact, and (3) the Osteological Paradox. We suggest that although this coastal environment exacerbated morbidity because of possible parasitic infection, the inhabitants were probably able to survive physiological stresses better than either their inland contemporaries or their modern counterparts.

Key words: paleodiet - pathoecology - stable isotopes - Diphyllobothrium - Maya

The objective of this study is to investigate relationships among disease (particularly anemia), diet, culture, and environment at the coastal sites of Marco Gonzalez and San Pedro in northern Belize (Fig. 1) during the Postclassic/Historic periods, which span the years 1350$1650 \mathrm{AD}$. Two dramatic cultural phenomena frame the temporal representation of this material: (1) the Classic period collapse, which occurred at many heartland sites before the sampled periods, and (2) the Spanish conquest, which ultimately affected all Maya sites. Both of these phenomena were associated with depopulation, for which disease (nutritional, parasitic, and infectious) has been hypothesized as a causative factor (Hooton 1940, Willey \& Shimkin 1973, Fariss 1984, Chase \& Rice 1985, Santley et al. 1986).

Much of the bioarchaeological research involving testing the ecological model of Maya collapse (Whittington \& Reed 1997, White 1999) arises from Hooten's (1940) observations of anemia among the sacrificial victims at Chichen Itza, and his challenge to archaeologists to consider malnutrition as a cause for the Classic period Maya collapse. According to the ecological model, rising population density necessitated intensification in the produc-

Finacial support: The Social Sciences and Humanities Research Council of Canada, the Natural Sciences and Engineering Research Council of Canada, the Canada Research Chairs program +Corresponding author: white2@uwo.ca

Received 20 July 2006

Accepted 16 October 2006 tion and consumption of maize, which in turn caused widespread environmental degradation. Malnutrition and disease became rampant, and the social, economic, and political fabric of the civilization was destroyed in most large Maya centres. Lesions associated with anemia, which include both porotic hyperostosis (Fig. 2a) and cribra

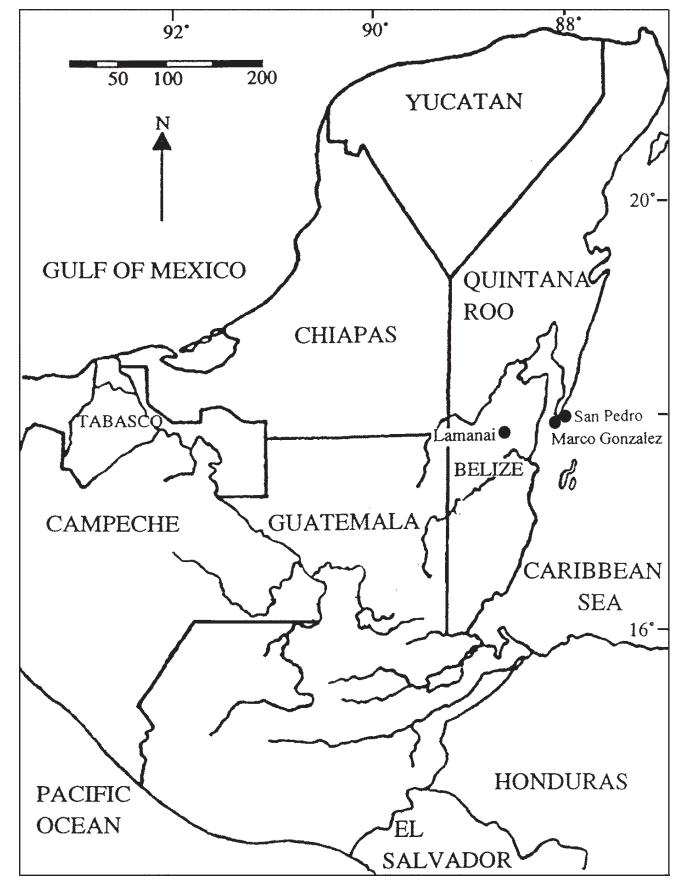

Fig. 1: map of Belize showing location of Marco Gonzalez and San Pedro (modified after Williams et al. 2006). 
orbitalia (Fig. 2b), are found in many in ancient Maya populations (e.g., Saul 1972, 1982, Kennedy 1983, White et al. 1994, Saul \& Saul 1991). However, Wright and White (1996) have noted that the incidence of these (and other) lesions does not rise consistently in relation to the Collapse. Furthermore Wright and Chew (1999) suggest that the ancient inhabitants of the region were more likely to survive anemia than modern ones, and thus may have been living in a healthier environment. Their research was a test of the Osteological Paradox, which states that populations with a high frequency of skeletal lesions may actually indicate an adaptive response because sick individuals cannot manifest lesions unless they survive their conditions for some time (Wood et al. 1992).

The degree to which Maya populations were affected by Spanish contact is largely speculative. Ethnohistoric accounts from the neighbouring Yucatan suggest that disease was already rampant by the time the Spanish arrived (Tozzer 1941, Clendinnen 1987) but at issue is whether these accounts more accurately reflect reality or the vested interests of the Spanish priests who wrote them. Skeletal analysis provides a means of determining the verity and/or limitations of the historical record of mortality and morbidity. The quintecentenary of Colum-
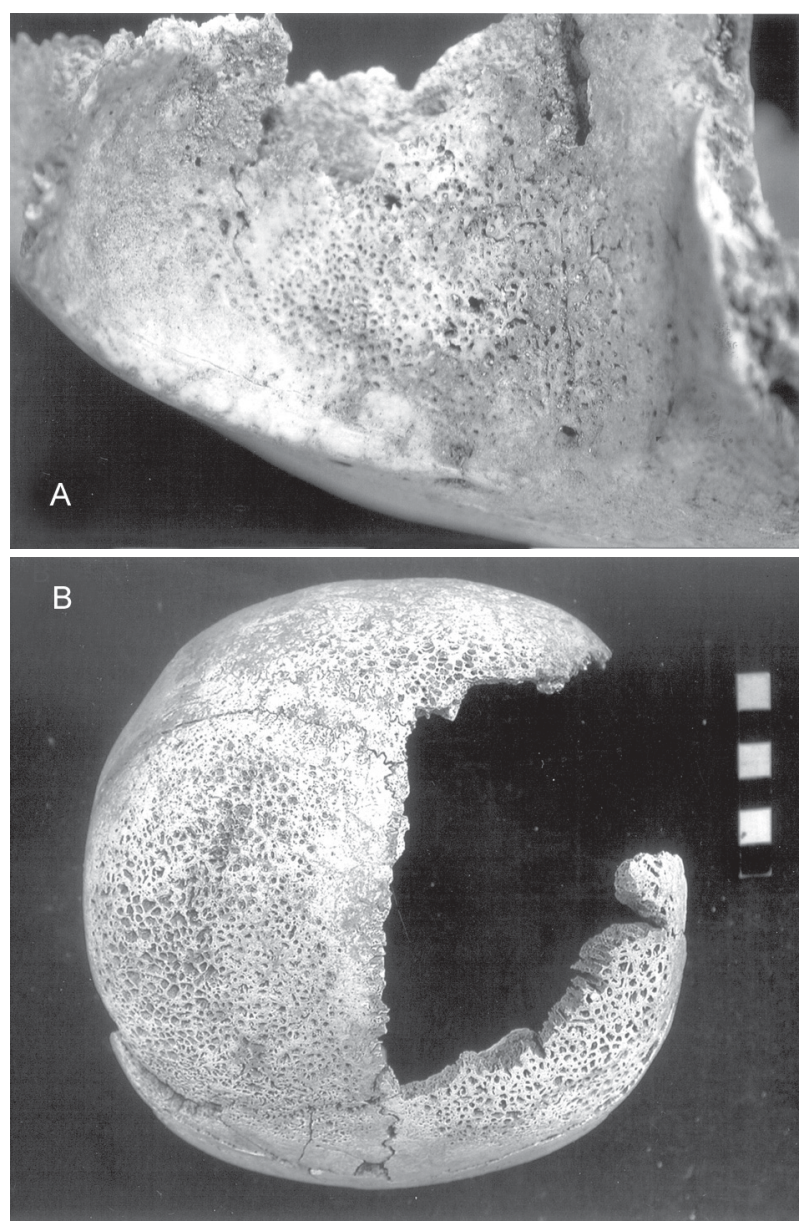

Fig. 2A: porotic hyperostosis (San Pedro burial 11 2/2); B: cribra orbitalia (San Pedro burial 11 2/7b). bus stimulated much research on the biological effects of the Spanish Conquest in the Americas (e.g. Verano \& Ubelaker 1992, Larsen \& Milner 1994), but this kind of research among Maya sites has been severely limited by both the historical focus of excavation designs on the recovery of earlier (Preclassic and Classic) material, and the very poor preservation of skeletal material in the tropical regions inhabited by many of the Maya.

Anemia is a "non specific" condition (i.e., it can have more than one cause) and the lesions associated with it are usually a measure of childhood health (Stuart-Macadam 1985, Stuart-Macadam \& Kent 1992). It has been argued that heavy consumption of maize causes anemia because it: (1) contains little iron (Garretson \& Conrad 1967), (2) contains phytate, which chelates iron from other dietary sources making it less available metabolically (Layrisse et al. 1969) and, (3) is processed with calcium carbonate, which also inhibits iron absorption (Wintrobe 1967). Additional factors that could contribute to anemia among the ancient Maya include: (1) prolonged breastfeeding without supplementation with iron-rich foods, (2) chronic infection, and (3) parasitism, especially types that result in blood loss.

This paper examines the ecology and etiology of anemia and possibly related conditions at two coastal Maya sites in order to investigate the mitigating or exacerbating effects of a coastal environment on susceptibility to morbidity during the periods immediately following the Classic collapse, i.e., the Postclassic and Historic.

\section{Site and sample description}

Marco Gonzalez and San Pedro are neighbouring sites located on the southern tip of Ambergris Cay in Northern Belize (Fig. 1). Ambergris Cay is a large island that would originally have been an extension of the Xcalec peninsula of Quintana Roo, Mexico but was separated from the mainland before $600 \mathrm{AD}$ when the Maya constructed a narrow channel (Glassman \& Garber 1999), probably to facilitate a faster trade route to rivers (i.e., Rio Hondo and New River) that emptied into the coast of Northern Belize. One of the most important environmental characteristics of the area is the barrier reef that runs parallel to the shore. The reef provided marine resources and also a breaker for ocean waves (Waddell 1981, Guderjan 1995) thus facilitating easy travel along the coast. These two locations were excavated between 1986 and 1993 by Elizabeth Graham and David Pendergast for the Royal Ontario Museum and are among approximately 22 other mostly unexcavated sites along the island's coast (Guderjan 1995). The skeletal sample consists of 143 relatively well-preserved individuals (97 from Marco Gonzalez, and 46 from San Pedro), which is a large sample size for a Maya site.

\section{MATERIALS AND METHODS}

Age-at-death was determined for each skeleton using dental development (Ubelaker 1989), pubic symphysis, sternal rib ends, long bone length (Phenice 1969, Krogman \& Isçan 1986), and epiphyseal closure (McKern \& Stewart 1957). Sex was determined using the standards normally used in forensic cases (e.g. Bass 1987, Buikstra \& Ubelaker 1994). 
Differential diagnoses and scoring of pathological conditions followed standard methods developed for osteologists (Steinbock 1976, Buikstra \& Ubelaker 1994, Ortner 2003). The pathological conditions analysed were porotic hyperostosis (Fig. 2a), cribra orbitalia (Fig. 2b), scurvy (Fig. 3), non-specific infection (periostitis, Fig. 4), and adult forms of spondyloarthropathy (Fig. 5). Both porotic hyperostosis and cribra orbitalia were considered to be lesions indicative of anemia. Cranial evidence of sub-adult scurvy was also evaluated using the criteria of Ortner and Erikson (1997) and Ortner et al. (1999, 2001).

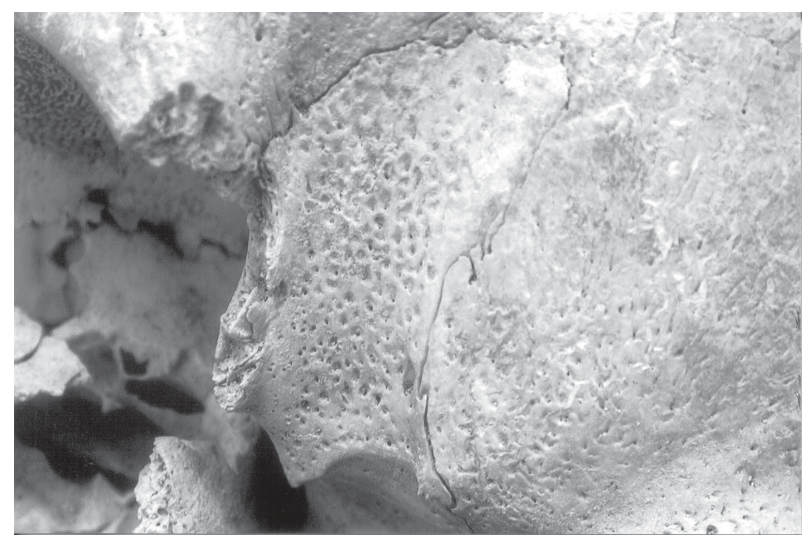

Fig. 3: example of scurvy (San Pedro burial 11-21).

Linear enamel hypoplasia (LEH) is a dental pathology that marks recovery from a non-specific stress strong enough to arrest growth, and commonly occurs as a result of weanling stress. Dolphin (2000) assessed the presence of LEH for all anterior teeth $(\mathrm{N}=1099)$, and calculated the frequency and timing of its formation using the scoring method proposed by the Federation Dentaire Internationale (1982), modified by Buikstra and Ubelaker (1994). In order to determine the age at which the defect was formed, growth standards specific to Maya populations were used (Wright 1997).

Stable carbon- and nitrogen-isotope ratios $\left({ }^{13} \mathrm{C} /{ }^{12} \mathrm{C}\right.$; ${ }^{15} \mathrm{~N} /{ }^{14} \mathrm{~N}$ ) in bone collagen and stable carbon-isotope ratios in the structural carbonate of bone apatite were analysed for 65 humans (Williams et al. in press, Fig. 6). Faunal samples $(\mathrm{N}=21)$ were also analysed to establish the isotopic composition of the reef food web (Fig. 6). These carbon- and nitrogen-isotope ratios are expressed in per mil $\left(\%{ }_{00}\right)$ as $\delta$-values using the formula:

$$
\delta=\left[\left(\mathrm{R}_{\text {sample }} / \mathrm{R}_{\text {standard }}\right)-1\right] \times 1000
$$

Carbon-isotope ratios are measured relative to the Vienna PDB (VPDB) standard (Coplen 1994) and the nitrogenisotope standard is purified atmospheric nitrogen calibrated using IAEA-N1 $(.4 \%)$ and IAEA-N2 $(+20.3 \%)$.

Both carbon and nitrogen-isotope ratios in collagen normally indicate the protein component of the diet. This component is derived from isotopically distinct plants $\left(\mathrm{C}_{3}\right.$ versus $\mathrm{C}_{4}$ ) at the bottom of the food chain as well as the level of the consumer in that food chain. In this region, vegetables, fruits, nuts, and legumes are $\mathrm{C}_{3}$ plants. However, the main terrestrial staple (maize) is $\mathrm{C}_{4}$. Unfortunately, the $\mathrm{C}_{4}$ signal from maize is likely confounded by the consumption of marine/reef foods because marine carbonates have higher $\delta^{13} \mathrm{C}$ values that mimic $\mathrm{C}_{4}$ sources. However, this problem is addressed through the use of nitrogen-isotope ratios, which are normally higher in marine than in terrestrial resources because of the greater number of trophic levels in marine food webs. Consumption of marine resources is also manifest by very small spacings between $\delta^{13} \mathrm{C}$ values in structural carbonate and collagen $\left(\Delta^{13} \mathrm{C}_{\text {sc-col }}\right)$ caused by different lipid/protein ratios in marine resources.

Separate analyses were done for both organic and mineral fractions of the bone to test for post-mortem alteration (DeNiro et al. 1985). These included carbon/nitrogen ratios (DeNiro et al. 1985), collagen yield (van Klinken 1999), $\mathrm{CO}_{2}$ yield (Ambrose 1990), crystallinity indices and calcium/phosphorus ratios (Wright \& Schwarcz 1996). These six indicators resulted in the elimination of only seven samples, which suggests generally excellent preservation for a Maya sample.

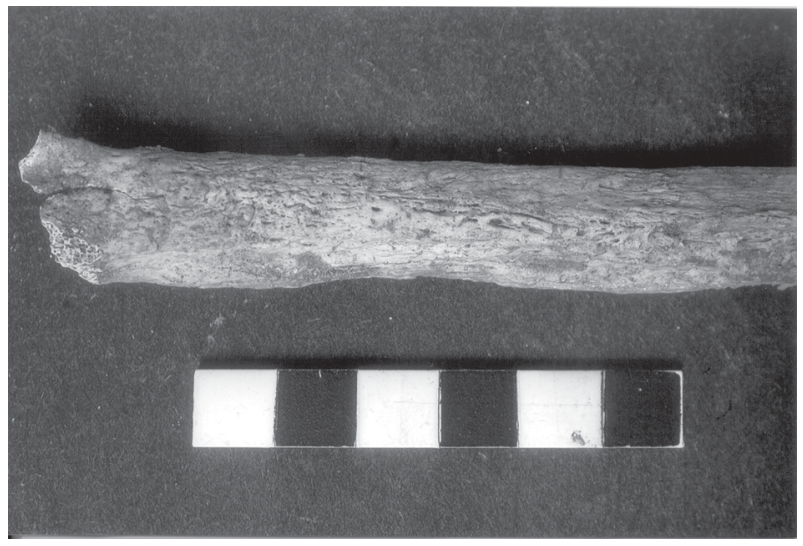

Fig. 4: example of periostitis (Marco Gonzalez burial 14/27).

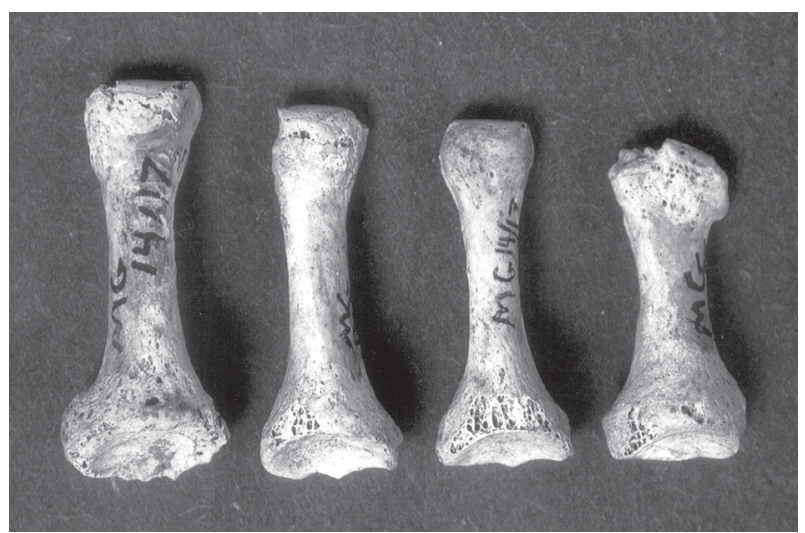

Fig. 5: example of spondyloarthopathy (Marco Gonzalez burial 14/ 17). 

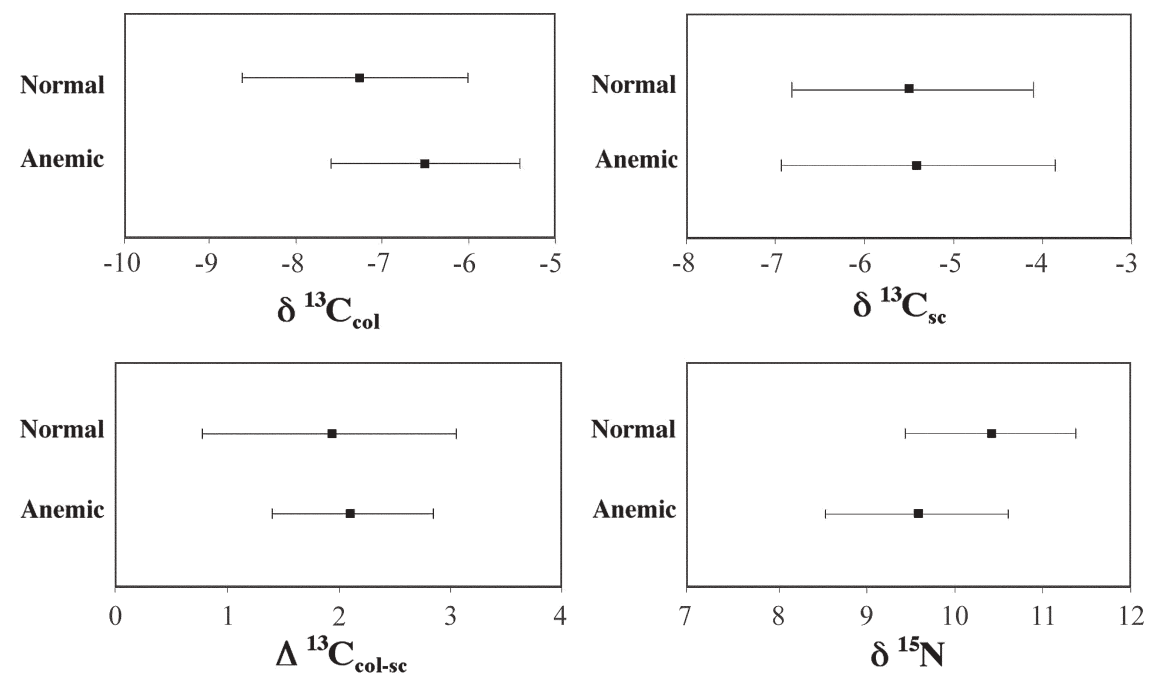

Fig. 6: model of isotopic compositions of resources in food web for Marco Gonzalez and San Pedro showing values for normal, anemic, and scorbutic individuals (modified after Williams et al. 2006).

\section{RESULTS}

Of the observable sample in both populations combined, $12 \%$ exhibited lesions indicative of anemia, which is a lower frequency than that found at many Maya sites from early time periods (Wright \& White 1999). Typical of what would be expected of a marine/reef environment, the diet at both sites is dominated by marine foods. There are no statistically significant differences in the isotopic measures between the two sites. Individuals with lesions indicative of anemia and those without have virtually identical compositions for their whole diets and their degree of carnivory (as illustrated by their structural carbonate $\left(\delta^{13} \mathrm{C}_{\mathrm{sc}}\right)$ values and carbonate-collagen spacings $\left(\Delta^{13} \mathrm{C}_{\mathrm{sc}}\right.$ col values), Table). These lesions do, however, seem to be related to the kind of protein consumed. The $\delta^{13} \mathrm{C}_{\text {col }}$ values of "anemic" individuals indicate a significantly greater consumption of foods with more positive $\delta^{13} \mathrm{C}$ values, which could have been either maize-based or marine/reefbased (Table). In addition, the lower $\delta^{15} \mathrm{~N}$ values (Table) in individuals with skeletal pathology suggest that their protein was derived from lower trophic level foods. Because the protein base was marine, they probably ate more shellfish, crustaceans and/or lower trophic level fish. In general, lower trophic level marine resources should be able to meet iron requirements (Sizer \& Whitney 2000), so insufficient dietary iron is not the likely cause of anemia at this site.

The hypothesis that anemia in these populations could have been caused by prolonged breastfeeding was tested by reconstructing the age of weaning using both isotopic measures and linear enamel hypoplasia. Previous studies have shown that nursing children have higher $\delta^{15} \mathrm{~N}$ values because they are one step higher in the food chain than their mothers (Fogel et al. 1989). Williams et al. (2005) found that although the majority of children at these sites mainly relied on breast-milk until the age of 3-4 years, there are a few individuals whose $\delta^{15} \mathrm{~N}$ values suggest consumption of breast milk, in addition to other foods, until the age of five years (Fig. 7a). Skeletal lesions indicative of anemia are created dominantly during childhood (normally after six months of breastfeeding if there is insufficient supplementation of iron-bearing foods), and are often sustained into adulthood (Stuart MacAdam 1985). Because dependence on breast feeding beyond six months puts an infant at risk for iron deficiency anemia, the prolonged nursing in these populations would certainly have predisposed children to this condition. Isotopic data reconstructing the commencement of weaning are also consistent with the timing of peak frequencies of linear enamel hypoplasia (Fig. 7b). As a non-specific stress indicator, linear enamel hypoplasia is commonly associated with weanling stress, e.g., diarrhea and infection that often accompany infants as they are weaned (Larsen 1997, but see Katzenberg et al. 1996). Thus both chemical and gross morphological measures of physiological change indicate the likelihood that anemia, weanling diarrhea, and infection were factors related to weanling stress.

The relationship between lesions indicative of anemia and linear enamel hypoplasia in this context bears further

TABLE

Comparison of isotopic measurements for anemic, scorbutic, and normal individuals

\begin{tabular}{lrlrlrr}
\hline & \multicolumn{2}{c}{$\begin{array}{c}\text { Anemic } \\
(\mathrm{n}=10)\end{array}$} & \multicolumn{2}{c}{$\begin{array}{c}\text { Scorbutic } \\
(\mathrm{N}=8)\end{array}$} & \multicolumn{2}{c}{$\begin{array}{c}\text { Normal } \\
(\mathrm{N}=49)\end{array}$} \\
\hline$\delta^{13} \mathrm{C}_{\mathrm{col}}$ & -6.5 & $1.1^{\alpha}$ & -5.7 & $0.4^{\alpha}$ & -7.3 & 1.3 \\
$\delta^{13} \mathrm{C}_{\mathrm{sc}}$ & -5.4 & 1.6 & -5.1 & 2.0 & -5.5 & 1.4 \\
$\Delta^{13} \mathrm{C}_{\mathrm{sc}-\mathrm{col}}$ & 2.1 & 0.7 & 1.4 & 0.7 & 1.9 & 1.2 \\
$\delta^{15} \mathrm{~N}$ & 9.6 & $1.1^{\alpha}$ & 10.1 & 1.8 & 10.4 & 1.0 \\
\hline
\end{tabular}

$a$ : statistically significant. 


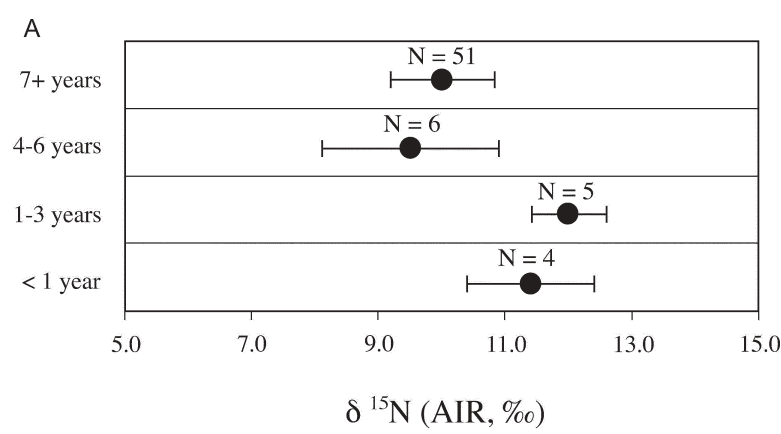

B

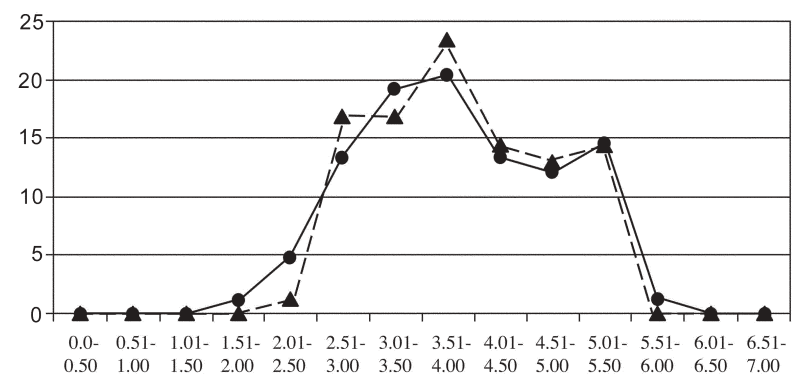

Fig. 7: age of weaning as shown by A: $\delta^{15} \mathrm{~N}$ values; B: linear enamel hypoplasia ( $\mathbf{\Delta}$ : Marco Gonzalez; $\bullet$ : San Pedro)

consideration even though they are both markers of childhood health. Anemia is a bony response to a chronic condition, whereas linear enamel hypoplasia reflects recovery from discrete stress episodes that may be either acute or recur chronically. Therefore, children who die from acute stress will not exhibit hypoplasia but they may still exhibit anemia. Childhood anemia can be a part of weaning stress because of prolonged breastfeeding, iron deficient, high carbohydrate dietary supplementation, the malabsorption of iron resulting from "weanling diarrhea", the propensity of children to be infected with parasites through their play, and the predisposition to infectious disease created by the synergism of the above factors, (e.g. Carlson et al. 1974, Lallo et al. 1977, Holland \& O'Brien 1997, Wright \& Chew 1999). Although the timing of hypoplastic stress episodes is consistent with the weaning period, the lesions of iron deficiency anemia may denote a different source and/or more prolonged periods of stress than linear enamel hypoplasia.

These populations also had high frequencies of subadult vitamin C deficiency (58\% with scurvy, Fig. 3), nonspecific infection ( $71 \%$ with periostitis, Fig. 4 ), and adult forms of spondyloarthropathy, which is a type of arthritis ( $10 \%$, Fig. 5) (Maxwell 2003, 2004). About half (47\%) of the observable 17 individuals had both scurvy and lesions indicative of anemia. Although these conditions are usually reported separately, their occurrence in the same individuals is not surprising because vitamin $\mathrm{C}$ facilitates iron absorption (Sizer \& Whitney 2000). Thus vitamin $\mathrm{C}$ deficiency would reduce the metabolic availability of consumed iron, contributing to both anemia and infection. Vitamin C deficiency is most commonly caused by dietary insufficiency, but the etiology also includes prolonged diarrhea and/or infection, and intestinal diseases, which are notably causes shared by anemia. The characteristic appearance and distribution of lesions described by Ortner (2003) result from the interference of vitamin $\mathrm{C}$ deficiency with collagen production (Fuchs \& Podda 1997). The $\delta^{13} \mathrm{C}_{\mathrm{col}}$ values for scorbutics (like those for anemics) are significantly higher than in normal individuals (Table). Further research will be needed to determine if this phenomenon is caused by a physiological effect related to collagen synthesis or a greater consumption of maize or marine foods. The isotopic data indicating trophic level $\left(\delta^{15} \mathrm{~N}\right.$ and $\Delta^{13} \mathrm{C}_{\mathrm{sc}-\mathrm{col}}$ values $)$ do not indicate significant differences in protein source consumption for scorbutics (unlike those for anemics). This finding might suggest that the occurrence of scurvy in this population is mainly secondary to anemia.

Most of the vitamin C deficiency found elsewhere in the Maya area has been in adults (Saul 1972, Kennedy 1983 ) and in the form of sub-periosteal hematomas rather than the cranial and joint lesions seen here. The diverse tropical environment of this region is rich in sources of vitamin $\mathrm{C}$ and even marine diets meet requirements for both vitamin C and iron (Sizer \& Whitney 2000). Therefore diet alone does not seem to provide a solid explanation for the cause of either anemia or scurvy in these coastal Maya. Rather, we are more likely seeing a synergism among disease, diet and ecology.

This hypothesis is also supported by extremely high frequencies of spondyloarthropathy (Maxwell 2004), a form of arthritis that is manifest by an aberrant immune response involving inflammation, bony deposition (entheses) and erosion of appendicular and axial joints (Resnik \& Niwayoma 1988). Spondyloarthropathy can take several forms (ankylosing spondylitis, reactive arthritis, psoriatic arthritis, enteric spondyloarthropathy, undifferentiated spondyloarthropathy) (Calin 1998). Its etiology can be genetic or environmental, i.e., it can be triggered by bacteria that cause low grade gastrointestinal and genitourinary infection (Calin 1998). The generalized normal frequency of this condition in most populations is $2-3 \%$, but it is present in $\sim 10 \%$ of this sample. The frequency of the spondyloarthropathy gene (HLA-B27) in modern Maya populations is between 4 and 20\% (Khan 1997). Marco Gonzalez and San Pedro were probably closely related and possibly genetically homogeneous according to their dental morphology and archaeological evidence (Graham \& Pendergast 1987, 1989, Pendergast \& Graham 1991). Although there could be a genetic basis to the occurrence of spondyloarthropathy here, population frequencies over 2-3\% generally indicate crowding and sanitation problems (Rothschild \& Rothschild 1993). Bacterial contamination of water is quite likely to have occurred given the natural environment of the cay, as well as the cultural activities it sustained (Graham pers. commun.). The population density and high water table could easily have exposed water sources to fecal contamination, and the island's geology may have prevented the replacement of contaminated water. In addition, extensive salt processing activities may have prevented adequate filtration of ground water. 
The possibility of parasitic infection as an important factor in the pathoecology of this site can be inferred from the dietary reconstruction. The lower trophic-level marine/reef diet of the affected inhabitants of the cay may have exposed them to helminthic parasites, particularly Diphyllobothrium or "broad fish tapeworm" species, which are common in low trophic level crustaceans. The protein sources of individuals with lesions indicative of anemia were from significantly lower trophic levels. Diphyllobothrium has an unusual ability to extract most of the host's vitamin B12, causing diarrhea, pernicious anemia, and bone formation anomalies. The definitive host (usually a sea mammal) of this parasite releases eggs into the water through defecation. The parasite is then passed through the food chain first via crustaceans, which are eaten by low trophic-level crustaceaneating fish, and then higher level fish-eating mammals (including humans). The juvenile worm develops to maturity (up to $12 \mathrm{~m}$ in length) in the small intestine of the definitive host (humans) and may survive longer than 10 years. Not surprisingly, Diphyllobothrium are most problematic for humans where sewage and fisheries come in contact. This kind of parasitic infection may not only have contributed to the occurrence of anemia, but also predisposed host individuals to vitamin $\mathrm{C}$ deficiency, and through weakened immune responses, contributed to the presence of periostitis and the severity of spondyloarthropathy found in these populations. There is very ancient evidence (4000-5000 BP) for the presence of Diphyllobothrium in coastal South American populations (Reinhard \& Urban 2003) but, in spite of the likelihood that they were also present in Mesoamerica several thousand years later, poor preservation has inhibited their discovery.

Regardless of which specific disease agents created the morbidity profile of these populations, multiple lines of evidence indicate that the coastal environment was conducive to endemic infection and the consequent appearance of malnutrition. The health problems faced by these people were, however, chronic rather than acute or life-threatening and therefore manifest in their skeletons. Consequently, the Osteological Paradox was probably a reality in this context. The major implication of this interpretation is that these Maya populations may well have been better able to survive than their modern counterparts, and perhaps even their ancient mainland contemporaries. At the same time, the high level of morbidity would seem to verify Spanish accounts of poor health in the neighbouring Yucatan.

\section{Conclusions}

Low trophic level dietary protein is statistically associated with lesions indicative of anemia, and high $\delta^{13} \mathrm{C}_{\mathrm{col}}$ values are associated with scurvy. Nonetheless, it is unlikely that lack of dietary nutrients was the primary cause of conditions associated with malnutrition and disease found in this context. Although these findings are preliminary as we continue to investigate the synergism of prolonged breastfeeding, vitamin $\mathrm{C}$ deficiency, infection, and anemia, we speculate that both physiology and eco- logical context played a major role in the disease experience of these coastal Maya. The co-occurrence of scurvy with lesions indicative of anemia, and the dental evidence for weanling stress suggest a high level of childhood morbidity. Similarly, the high frequency of spondyloarthr-opathy indicates that adult populations were also at risk for ecologically based disease. These findings are consistent with Spanish ethnohistoric descriptions of the poor state of Maya health at the time of contact. Notably, however, these ancient populations had to survive their stresses long enough to manifest skeletal lesions, unlike what appears to be happening with their modern counterparts (Wright \& Chew 1999). In spite of its appearance as a distinctly unhealthy place to live, the ancient environment may, indeed, have been healthier than the modern one.

\section{ACKNOWLEDGEMENTS}

To Elizabeth Graham, University College, London, and David Pendergast, Royal Ontario Museum (who excavated the sites and provided samples), and Kimberley Law, The University of Western Ontario (who provided technical assistance).

\section{REFERENCES}

Ambrose SH 1990. Preparation and characterization of bone and tooth collagen for isotopic analyses. J Arch Sci 17: 431-451.

Bass Wm 1987. Human Osteology: A Laboratory and Field Manual, Missouri Archaeological Society, Columbia.

Buikstra JE, Ubelaker DH 1994. Standards for Data Collection from Human Skeletal Remains, Arkansas Archaeological Survey Research Series No. 44, Arkansas.

Calin A 1998. Terminology introduction, diagnostic criteria, and overview. In A Calin, J Taurog (eds), The Spondyloarthritides, Oxford University Press, Oxford, p. 1-16.

Carlson DS, Armelagos GJ, van Gerven DP 1974. Factors influencing the etiology of cribra orbitalia in prehistoric Nubia. $J$ Hum Evol 3: 405-410.

Chase AF, Rice PM 1985. The Lowland Maya Postclassic, University of Texas Press, Austin.

Clendinnen I 1987. Ambivalent Conquests: Maya and Spaniard in Yucatan, 1517-1570, Cambridge University Press, Cambridge.

Coplen TB 1994. Reporting of stable hydrogen, carbon and oxigen isotopes abundances. Pure and Applied Chem 66: 271-276.

DeNiro MJ, Schoeninger MJ, Hastorf CA 1985. Effect of heating on the stable carbon and nitrogen isotope ratios of bone collagen. J Arch Sci 12: 1-8.

Dolphin AE 2000. Marco Gonzales and San Pedro, Belize: a Comparison of Juvenile Health between Postclassic Maya Sites, MA Thesis, Department of Antropology, The University of Western Ontario.

Fariss NM 1984. Maya Society under Colonial Rule, Princeton University Press, Princeton, NJ.

Fogel ML, Tuross N, Owsley DW 1989. Nitrogen isotope tracers of human lactation in modern and archaeological populations. In Carnegie Institution of Washington Yearbook, Geophysical Laboratory, Washington, p. 111-117.

Fédération Dentaire Internationale 1982. An epidemiological in- 
dex of developmental defects of dental enamel (DDE index). Int J Dent 302: 157-167.

Fuchs J, Podda M 1997. Vitamin C in cutaneous biology. In L Packer, J Fuchs (eds), Vitamin C in Health and Disease, Marcel Dekker Inc., New York, p. 333-340.

Garretson FC, Conrad ME 1967. Starch and iron absorption. Proc Soc Exper Bio Med 126: 304-308.

Glassman DM, Garber JF 1999. Land use, diet and their effects on the biology of the prehistoric Maya of northern Ambergris Cay, Belize. In CD White, Reconstructing Ancient Maya Diet. University of Utah Press, Salt Lake City, p. 119-132.

Graham E, Pendergast D 1987. Cays to the kingdom. ROM Arch Newsletter 2: 1-4.

Graham E, Pendergast D 1989. Excavations at the Marco Gonzalez site, Ambergris Cay, Belize. J Field Arch 16: 116.

Guderjan TH 1995. Maya settlement and trade on Ambergris Cay, Belize. Anc Meso 6: 147-159.

Holland TD, O’Brien MJ 1997. Parsites, porotic hyperostosis and the implications of changing perspectives. Am Antiq 62: 183-193.

Hooton EA 1940. Skeletons from the cenote of sacrifice at Chichen Itzá. In CL Hay, The Maya and their Neighbors, Appleton-Century, New York, p. 272-280.

Katzenberg, MA, Herring DA, Saunders SR 1996. Weaning and infant mortality: evaluating the skeletal evidence. Yrbk Phys Anthropol 39: 177-199.

Kennedy GE 1983. Skeletal remains from Sartejena, Belize. In RV Sidrys, Archaeological Excavations in Northern Belize, Central America, Monograph XVII, Institute of Archaeology, UCLA, Los Angeles.

Khan AK 1997. Prevalence of HLA-B27 in world populations. In C Lopez-Larrea, HLA-B27 in the Development of Spondyloarthropathies, RG Landes Co., Austin, p. 95-112.

Krogman WM, Isçan MY 1986. The Human Skeleton in Forensic Medicine, Charles C Thomas, Springfield.

Lallo JW, Armelagos GJ, Mensforth RP 1977. The role of diet, disease and physiology in the origin of porotic hyperostosis. Hum Biol 49: 471-483.

Larsen CS 1997. Bioarchaeology: Interpreting Behavior from the Human Skeleton, Cambridge University Press, Cambridge.

Larsen CS, Milner GR 1994. In the Wake of Contact: Biological Responses to Conquest, Wiley-Liss, New York.

Layrisse MJ, Cook JD, Martinez C, Roch M, Kuhn IN, Walker RB, Finch CA 1969. Food iron absorption: a comparison of vegetable and animal foods. Blood 33: 430-433.

Maxwell J 2003. Evaluating Morbidity and Mortality in Skeletal Remains: An Analysis of Paleopathology at the Maya Sites of Marco Gonzalez and San Pedro, Belize, MSc Thesis, Department of Anthropology, The University of Western Ontario.

Maxwell J 2004. Exceptionally high levels of spondyloarthropathy in two coastal Maya populations. Paper presented at Annual Meeting of the Canadian Association for Physical Anthropology, London, Canada.
McKern TW, Stewart TD 1957. Skeletal age changes in young American males, Quatermaster Research and Development Command, Technical Report EP-45, Natick, MA.

Ortner DJ 2003. Identification of Pathological Conditions in Human Skeletal Remains, 2nd ed., Academic Press, San Diego.

Ortner DJ, Eriksen MF 1997. Bone changes in the human skull probably resulting from scurvy in infancy and childhood. Int J Osteoarch 7: 212-220.

Ortner DJ, Butler W, Cafarella J, Milligan L 2001. Evidence of probably scurvy in subadults from archaeological sites in North America. Am J Phys Anthropol 114: 343-351.

Ortner DJ, Kimmerle EH, Diez M 1999. Probable evidence of scurvy in subadults from archaeological sites in Peru. Am J Phys Anthropol 108: 321-331.

Pendergast DM, Graham E 1991. The town beneath the town: 1991 excavations at San Pedro, Ambergris Cay, Belize. ROM Arch News 2: 1-4.

Phenice TW 1969. A newly developed visual method of sexing the os pubis. Am J Phys Anthropol 30: 297-301.

Reinhard K, Urban O 2003. Diagnosing ancient Diphyllobothriasis from Chinchorro mummies. Mem Inst Oswaldo Cruz 98 (Suppl. 1): 191-193.

Resnick, D, Niwayama G 1998. Diagnosis of Bone and Joint Disorders, 2nd ed., WB Saunders Co., Philadelphia.

Rothschild BM, Rothschild C 1993. 19th Century spondyloarthropathy independent of socioeconomic status: Lack of skeletal collection bias. J Rheum 20: 314-319.

Santley RS, Killion TW, Lycett MT 1986. On the Maya collapse. J Anthropol Res 42: 123-159.

Saul FP 1972. The human skeletal remains of altar de sacrificios: an osteobiographical analysis. Papers of the Peabody Museum of Archaeology and Ethnology Vol. 63, No. 2. Cambridge, Mass.

Saul FP 1982. The human skeletal remains from Tancah, Mexico. Appendix II. In AG Miller, On the Edge of the Sea: Mural Painting at Tancah-Tulum, Quintana Roo, Mexico, Dumbarton Oaks, Washington, p. 115-128.

Saul FP, Saul JM 1991. The preclassic population of Cuello. In N Hammond, Cuello: An Early Maya Community, Cambridge University Press, Cambridge.

Sizer F, Whitney E 2000. Nutrition: Concepts and Controversies, 8th ed., Wadsworth, Scarborough, Ontario.

Steinbock RT 1976. Paleopathological Diagnosis and Interpretation, Charles C Thomas, Springfield.

Stuart-Macadam P 1985. Porotic hyperostosis: Representative of a childhood condition. Am J Phys Anthropol 66: 391-398.

Stuart-Macadam P, Kent S 1992. Diet, Demography, and Disease: Changing Perspectives on Anemia, Aldine de Gruyter, New York.

Tozzer AM 1941. Landa's relación de las cosas de Yucatán. Papers of the Peabody Museum of American Archaeology and Ethnology No. 18, Harvard University.

Ubelaker DH 1989. Human Skeletal Remains, Taraxacum Press, Washington, D.C. 
Van Klinken GJ 1999. Bone collagen quality indicators for paleodietary and radiocarbon measurements. J Arch Sc 26: 687-695.

Verano JW, Ubelaker DH 1992. Disease and Demography in the Americas, Smithsonian Institution Press, Washington.

Wadell DAG 1981. British Honduras: A Historical and Contemporary Survey, Greenwood Press, Westport.

White CD 1999. Reconstructing Ancient Maya Diet, University of Utah Press, Salt Lake City.

White CD, Wright LE, Pendergast DM 1994. Biological disruption in the Early Colonial period at Lamanai. In CS Larsen, G Milner (eds), In the Wake of Contact: Biological Responses to Conquest, Wiley-Liss, New York, p. 135-145.

Whittington SL, Reed DM 1997. Bones of the Maya: Studies of Ancient Maya Skeletons, Smithsonian Institution Press, Washington, D.C.

Williams JS, White CD, Longstaffe FJ 2006. Maya marine subsistence: Isotopic evidence for trade and status from Marco Gonzalez and San Pedro, Belize. Latin Am Antiq (in press).

Williams JS , White CD, Longstaffe FJ 2005 Trophic level and macronutrient shift effects associated with the weaning pro- cess in the Maya Postclassic. Am J Phys Anthropol 128: 781-790.

Willey GR, Shimkin DB 1973. The Maya collapse: A summary view. In TP Culbert, The Classic Maya Collapse, University of New Mexico Press, Albuquerque, p. 457-502.

Wintrobe MM 1967. Clinical Hematology, Lea and Febiger, Philadelphia.

Wood JW, Milner GR, Harpending HC, Weiss KM 1992. The osteological paradox: problems of inferring prehistoric health from skeletal samples. Curr Anthropol 33: 343-370.

Wright LE 1997. Intertooth patterns of hypoplasia expression: implications for childhood health in the Classic Maya collapse. Am J Phys Anthropol 102: 233-247.

Wright LE, Chew F 1999. Porotic hyperostosis and paleoepidemiology: A forensic perspective on anemia among the ancient Maya. Am Anthropol 100: 924-939.

Wright LE, Schwarcz HP 1996. Infrared and isotopic evidence for diagenesis of bone apatite at Dos Pilas, Guatemala: Paleodietary implications. J Arch Sci 23: 933-944.

Wright LE, White CD 1996. Human biology in the Classic Maya collapse: Evidence from paleopathology and paleodiet. $J$ World Prehis 10: 147-198. 